\title{
Your rule of law is not mine: rethinking empirical approaches to $\mathbf{E U}$ rule of law promotion
}

\author{
Marc Hertogh ${ }^{1}$
}

Published online: 24 September 2015

(C) The Author(s) 2015. This article is published with open access at Springerlink.com

\begin{abstract}
The promotion of the "Rule of Law" is a leading ambition of the EU's external action (Article $21 \mathrm{TEU}$ ). The dominant approach in most policy documents is to define the rule of law in terms of legal and institutional checklists. However, several authors have criticized this "anatomical" approach and have argued for a "sociological" approach. In this paper, I will discuss two empirical models of the rule of law. Most current studies follow the model of the "Rule of Law in Action." This approach is based on Roscoe Pound's distinction between the "law in the books" and the "law in action." I will argue that this conventional approach has several shortcomings. I will therefore introduce an alternative model, based on Eugen Ehrlich's concept of the "living law." The principal concern of the "Living Rule of Law" model is not the level of social support but rather the social definition of the rule of law. To assess the strengths and weaknesses of both approaches, I will apply both models in a case study about rule of law reform in a refugee camp on the Thailand-Burma border. It will be concluded that empirical research is essential to evaluate the EU's external action. Moreover, empirical studies based on the model of the Living Rule of Law support a legal pluralist approach, which focuses on the user perspective of citizens and which recognizes the contested notion of the rule of law across cultural borders.
\end{abstract}

\section{Introduction}

The promotion of the "Rule of Law" is a leading ambition of the EU's external action vis-à-vis emerging powers like Brazil, Russia, India, China, and South Africa. According to Article 21 of the Treaty on European Union, "the Union's action on the international scene shall be guided by the principles which have inspired its own creation, development and enlargement, and which it seeks to advance in the wider world." These principles include democracy, human rights, and the rule of law. Thus

Marc Hertogh

m.l.m.hertogh@rug.nl

1 Department of Legal Theory, Faculty of Law, University of Groningen, PO Box 716, 9700 AS Groningen, Netherlands 
far, the focus of the EU on the rule of law has been mostly studied from a legal perspective. Some authors have, for instance, analyzed the place of the rule of law in the EU treaties (Pech 2012; Wouters and Ramopoulos 2013). Others have criticized the fact that, while the EU puts great emphasis on the Rule of Law in both its internal and external policies (Pech 2012, 78), it has never provided a clear definition of this key concept (Kochenov 2004). However, in addition to these legal issues, the focus on the rule of law also raises important empirical questions.

Most importantly, scholars have pointed to the fact that most programs to promote the rule of law abroad have not been very successful. Brooks claims, for instance, that "despite billions of aid dollars [...] there have been few rule of law success stories" (2003, 2280). Likewise, Peerenboom et al. argue that "the failures and problems of rule of law promotion are too striking to be ignored" $(2012,306)$. Moreover, there is a serious "lack of systematic, well-grounded knowledge about how external aid can be used promote the rule of law in other countries" (Carothers 2006, 25). This criticism also raises important empirical questions for the EU's external action. It has been argued that, in general terms, promoting the rule of law "advances both principles and profits" (Carothers 1998, 95). This also applies to the EU's promotion of the rule of law. It is a normative project, aimed at exporting those values and principles that increase support for human rights and democracy (Manners 2002), but it is also an instrumental project built on the idea that a society governed by the rule of law is "more likely [...] to enjoy peaceful as well as economic growth" (Pech 2012, 7). But, how effective is the EU in achieving these goals? And, what explains this (lack of) success?

The aim of this paper, therefore, is to develop an empirical approach to the rule of law, which may inform future legal and political debates on EU rule of law promotion. In the next section, I will first present a brief review of the literature (see the "From an anatomical to an empirical approach" section). It will be argued that the dominant approach in the literature is to define the rule of law solely in terms of legal norms and institutions (see, e.g., Tamanaha 2004; Dicey 1939; Fuller 1969). However, more recently, several authors have criticized this "anatomical" approach and have argued for a more "sociological" or empirical approach to the rule of law (Krygier 2007, 2011; Nicolaidis \& Kleinfeld 2012). Most current empirical studies measure a country's level of compliance with the rule of law, using checklists and other indexes (see, e.g., Merkel 2012; Merry 2011). In the "From an instrumental to a constitutive approach" section, I will further examine this approach and I will also introduce an alternative perspective, using two empirical models of the rule of law. I will argue that most present studies follow the model of the "Rule of Law in Action," which is essentially based on Roscoe Pound's distinction between the "law in the books" and the "law in action" (1910). By contrast, I will introduce the model of the "Living Rule of Law," based on Eugen Ehrlich's concept of the "living law" (1936). The principal concern of this model is not the level of social support but rather the social and cultural definition of the rule of law. To assess the strengths and weaknesses of both approaches, and based on McConnachie's work (2014), I will then apply both models in a case study about the promotion of the rule of law in a refugee camp on the Thailand-Burma border (see the "Case study: refugee camps on the ThaiBurma border" section). Although the EU is currently not directly involved in this area, the strategy of top-down legal reform followed by the donor organizations in 
this case is similar to the present EU rule of law approach in other countries. I will argue, therefore, that the lessons from this case are highly relevant for understanding the success and failure of the EU's (future) external action aimed at promoting the rule of law, also considering the EU's growing interest in Southeast Asia. In the "Lessons for rule of law promotion" section, it will be concluded that empirical research is essential to evaluate the EU's external action. Moreover, empirical studies based on the model of the Living Rule of Law support a legal pluralist approach to EU rule of law reform, which focuses on the user perspective of citizens and which recognizes the contested notion of the rule of law across cultural borders.

\section{From an anatomical to an empirical approach}

Most discussions in the literature start with a definition of the rule of law. Rule of law theories are usually divided into two types: "thin" (procedural) or "thick" (substantive) theories (see, e.g., Tamanaha 2004; Zürn et al. 2012; Hachez and Wouters 2013). In addition, Krygier has argued that most authors follow what he refers to as an "anatomical approach" to the rule of law $(2007,3)$. First, their focus is on "legal institutions and the norms and practices directly associated with them." Second, a list of such institutions and practices is presented as "adding up to the rule of law" (Krygier 2007,3). Perhaps one of the most famous examples on this approach is Albert Venn Dicey's (1939) three-point definition of the rule of law. A second influential example is the way in which Lon Fuller (1969) has introduced a list of elements that, in his view, characterize "the internal morality of law." This list has also been adopted to constitute the conditions for the rule of law.

However, this anatomical approach to the rule of law is not limited to lawyers and legal philosophers, but it is also popular among policy-makers. One important example is the European Commission. In its recent Communication to the European Parliament and the Council, the Commission introduced "A new EU framework to strengthen the Rule of Law" (European Commission 2014). In this document, the Commission presented a list of principles which, in its view, "define the core meaning of the rule of law as a common value of the EU in accordance with Article 2 TEU" (European Commission 2014, 4). These principles include the following:
(a) Legality
(b) Legal certainty
(c) Prohibition of arbitrariness of the executive powers
(d) Independent and impartial courts
(e) Effective judicial review including respect for fundamental rights
(f) Equality before the law

Similar to Krygier's definition of an anatomical approach, this list focuses on legal institutions and the norms and practices directly associated with them and the list is presented as adding up to the rule of law (Krygier 2007, 3; Nicolaidis \& Kleinfeld 2012, 13). 


\section{Toward an empirical approach}

This anatomical approach to the rule of law has recently come under attack by several authors. In their view, writing up a "laundry list" (Waldron 2002, 154) of features of a healthy legal system is one thing, but the realization of these ideas and institutions in practice is quite another. There is also growing interest in a sociological or empirical approach of the rule of law (see, e.g., Nicolaidis \& Kleinfeld 2012). For example, according to Krygier, "some of the central questions about the rule of law are sociological ones" $(2007,1)$.

Thus far, the most widely used empirical approach is to measure a country's level of compliance with the rule of law, using several checklists including the World Justice Project (WJP) index, ${ }^{1}$ the Worldwide Governance Indicators (WGI) ${ }^{2}$, and the UN Rule of Law indicators ${ }^{3}$ (see, e.g., Merkel 2012; Botero et al. 2011; Merry 2011). Although this type of research is useful, it has three important shortcomings: It has a strong ideological bias, it focuses almost exclusively on the opinions of lawyers and other legal experts, and it leaves important social norms unexplored. All three shortcomings will be explained below.

\section{Ideological bias}

First, most current empirical studies use a fixed definition of the rule of law, based on a particular (legal or political) ideology. For example, some authors have criticized the fact that "for many, 'the rule of law' means a [Western] liberal democratic version of rule of law" (which incorporates free market capitalism and multiparty democracy), while relatively little work exists to clarify "alternative conceptions of rule of law in other parts of the world" (Peerenboom 2002, 473). Others have criticized the "ideological abuse" (Shklar, cited in Waldron 2002, 139) of the rule of law. In this way, the rule of law becomes just another "self-congratulatory rhetorical device" (ibid) meaning little more than "Hooray for our side!" (Waldron 2002, 139). This normative bias is also reflected in those empirical studies that measure the level of compliance with the rule of law in other countries, using checklists or indexes. As Kahn has argued, "We measure their progress - or lack of it - against our end. [...] We have a missionary zeal, believing our truth to be revealed truth" $(1999,4)$.

\section{Focus on lawyers and experts}

Second, most previous empirical research builds on the rule of law as seen by legal experts and policy makers. These studies reflect a "rule of law orthodoxy" (see, e.g., Golub 2003; Van Rooij 2012). This approach is "largely determined by the legal profession, as represented by a nation's jurists, top legal officials, and attorneys, and by foreign consultants and donor personnel" (Golub 2003, 9). A similar approach was followed by the Venice Commission (Council of Europe), whose work contributed to the development of the new EU framework to strengthen the rule of law (see European

\footnotetext{
${ }^{1} \mathrm{http} / / /$ worldjusticeproject.org/ Accessed 10 March 2015.

2 http://www.govindicators.org Accessed 10 March 2015.

${ }^{3}$ http://www.unrol.org/ Accessed 10 March 2015.
} 
Commission 2014, 3). Although the Venice Commission (2011, 3; emph. added) claims that its goal is "to identify a consensual definition of the rule of law," its final report focuses almost exclusively on the views of legal experts. The Commission writes that, "[l] ooking at the legal instruments, national and international, and the writings of scholars, judges and others, it seems as if there is now a consensus on the core meaning of the rule of law and the elements contained within it" (Venice Commission 2011, 9). Many other studies follow a similar approach. As a result, empirical studies on the rule of law "overlook the key actors in this game: citizens" (Nicolaidis \& Kleinfeld 2012, 15). We know the opinion of legal experts, but what does the general public think about the rule of law?

\section{Social norms unexplored}

Third, although current empirical research has identified several obstacles for the promotion of the rule of law, it still leaves many important questions unanswered. Following Inayatullah and Blanley's (2004) general argument that International Relations (IR) scholarship has not been sensitive enough to important political, religious, and ideological differences, Kygier has argued that " $[\mathrm{t}]$ he rule of law [...] has to be in sync with local ecologies" (2011, 86; emp. added). Similarly, Nicolaidis and Kleinfeld argue that a credible assessment of the Rule of Law in a country must be informed by an investigation of "cultural patterns as reflected both in general beliefs and in specific behavior" (2012, 24; emph. added). But, what are the main characteristics of these "local ecologies"? And, how should we identify the most relevant "cultural patterns"?

In order to examine the implications of these shortcomings of the current research, and to explore a possible alternative perspective, we need to go back to the beginning in sociology of law. As will be demonstrated below, the early work by Roscoe Pound and Eugen Ehrlich provides a fruitful source of inspiration for developing an empirical approach to the rule of law.

\section{From an instrumental to a constitutive $\operatorname{approach}^{4}$}

Roscoe Pound (1870-1964) and Eugen Ehrlich (1862-1922) are considered two major contributors to modern sociology of law. Many commentators take the view that their ideas on law and society are very similar and that Pound's law in action in fact builds on Ehrlich's living law (see, e.g, Ziegert 1979). Yet, despite the fact that they were near contemporaries and both had a special interest in legal reality, their approaches are in fact very different and produce two different empirical models of the rule of law (Nelken 1984; Hertogh 2004b).

\section{Pound and Ehrlich}

Central to Pound's view on law and society is the way he distinguishes the law in books from the law in action: "the rules that purport to govern the relations of men" and "those that actually govern them" (Pound 1910, 15). To Pound, the law is not an

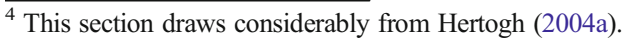


autonomous system of formal rules, but an important tool for social change. Judges and other lawyers should act as "social engineers" and apply the law to prevent or to address social conflict. To be the most effective, the official law needs to be constantly updated and amended to legal reality to bridge the gap between the law in books and the law in action.

To Ehrlich, court rulings and state legislation are "norms for decision." These norms tell judges and government officials how to perform their tasks. Society as a whole is considered a collection of social associations, "a plurality of human beings who, in relations with one another, recognize certain rules of conduct as binding, and generally at least, regulate their conduct according to them" (Ehrlich 1936, 39). Ehrlich calls these rules the living law. "The living law is the law which dominates life itself even though it has not been posited in legal propositions" (Ehrlich 1936, 493). To Ehrlich, the need for norms for decision arises only in cases of dispute and conflict, whereas living law prevails under normal circumstances (Hertogh 2009).

The most significant difference between these two views on law and society is their central focus on two completely different objects. Whereas Pound focused on the behavior of legislators, judges, jurists, and other legal officials, Ehrlich was oriented toward the behavior of people in social associations (inside and outside legal institutions). The law in books refers solely to (official) rules and norms. In this way, it can be distinguished from the law in action, the application of these rules and norms in legal practice. Norms for decision, on the other hand, include not only rules and norms but also the actual patterns of decision by legislative and judicial bodies. Conversely, living law is not identical to law in action because it refers essentially to obligatory norms rather than action. Ehrlich's norms for decision therefore encompass most of what Pound meant by both the law in books and the law in action. But, Ehrlich's notion of living law has no parallel in Pound's distinction.

\section{Two empirical models of the rule of law}

Both views on law and society can be used as an inspiration for two models of the rule of law: the Rule of Law in Action and the Living Rule of Law (Table 1). Each model represents a different approach to the empirical analysis of the rule of law. Pound's central distinction between the law in books and the law in action may also be applied to the rule of law. The "Rule of Law in Books" then refers to the legal definition of the rule of law that is, for instance, referred to in legal doctrine. The Rule of Law in Action looks at the degree to which these legal principles are implemented in legal practice.

Table 1 Two empirical models of the rule of law

\begin{tabular}{lll}
\hline & Rule of Law in Action & Living Rule of Law \\
\hline Inspiration & Law in action (Pound) & Living law (Ehrlich) \\
Perspective & Top-down & Bottom-up \\
Rule of law & Independent variable & Dependent variable \\
Focus & Social support & Social definition \\
Empirical research & Instrumental & Constitutive \\
\hline
\end{tabular}


Whereas the latter can be studied by reading law books and studying court decisions; the former requires empirical research. Similar to Pound's general theory of law and society, this type of empirical study focuses on the gap between the Rule of Law in Books and the Rule of Law in Action and on possible ways to bridge this gap.

Ehrlich's central concept of the living law may also be translated into a model for empirical research: the Living Rule of Law. This refers to all social norms and values that dominate life itself, even though they have not been posited in law (or in the legal definition of the rule of law). Unlike the previous model, this model is not directly connected to the "official" definition of the rule of law. Empirical research based on this second model is not interested in measuring the effectiveness of the legal version of the rule of law in legal practice; instead, it focuses on the values of society itself.

The first model (Rule of Law in Action) takes the legal definition of the rule of law - as it is discussed and agreed upon among lawyers, officials, and other expertsas its central reference point to study legal reality (top-down). The second model (Living Rule of Law) focuses on everyday legal practice (bottom-up). The first model treats the rule of law more or less as a given fact which is excluded from the empirical inquiry (independent variable). By contrast, the second model includes the rule of law in the empirical study as well (dependent variable). Whereas in the first model, the primary focus is the level of social support for the legal concept of the rule of law, the second model focuses on the social definition of the rule of law. What do members of a given community themselves consider important (regardless of the law)?

Finally, both models rely on a different type of empirical research. Those studies that follow the first model use an "instrumentalist" approach to empirical research, primarily aimed at identifying important gaps between the Rule of Law in Books and the Rule of Law in Action and at finding effective (policy) remedies to close this gap. Conversely, empirical studies that follow the second model are based on a "constitutive" approach. Rather than focusing on an evaluation of the effectiveness of the rule of law, it places in the center of the analysis people's own understandings of the rule of law (Fleury-Steiner and Nielsen 2006, 1).

While the model of the Rule of Law in Action focuses on "legal legitimacy" (aimed at measuring the level of adherence to human rights and international law), the model of the Living Rule of Law focuses on "sociological legitimacy" (aimed at analyzing the perceptions of people themselves) (McConnachie 2014, 112/159). This approach is closely linked to "legal consciousness" studies, which use ethnographic methods to analyze how people experience law in their everyday lives (see, e.g., Hertogh 2004b; Holzer 2013).

\section{From measuring to understanding the rule of law}

Most current empirical studies follow the Rule of Law in Action model. As demonstrated in the previous section, those studies that utilize indexes or indicators are based on a particular "given" definition of the rule of law. Moreover, these studies are aimed at "measuring countries' compliance" (Pech 2012, 36) with this definition of the rule of law. Closely following Pound's approach, it is suggested that "entrenching the 'Rule of Law' requires shifting our attention from the positive law of that country ("law in the books"), to how 
it is applied and enforced in practice ("law in action")" (Nicolaidis and Kleinfeld 2012, 23). Finally, most of these studies have an instrumental (policy) focus, aimed at closing the gap between both types of law. For example, with regard to the World Justice Project, Pech $(2012,41)$ argues that "the WJP index offers a sound footing on the basis of which one can assess practical compliance with the rule of law in any given country, identify weaknesses and strengths, which in time should help devise appropriate policies [...]" $(2012,41)$.

As discussed in the previous section, this particular empirical approach to the rule of law has several important shortcomings. Most importantly, by treating the definition of the rule of law as an independent variable, we may easily overlook alternative understandings. In the real world, the rule of law has many different faces; some are strange and some are familiar. We need to look at all of these, but we miss most of them if we only focus on the ones we like. And, that is exactly what happens if we only look through the lens of the lawyer, the philosopher, or the policy-maker (Hertogh 2013). In order to study the consequences of these shortcomings, and to explore the possible benefits of an alternative approach, in the next section, both empirical models of the rule of law will be applied in a case study.

\section{Case study: refugee camps on the Thai-Burma border}

This exploratory case study focuses on rule of law reform in a refugee camp on the Thailand-Burma border. This case study is based on Kirsten McConnachie's (2014) recent book Governing Refugees: Justice, Order and Legal Pluralism, which analyzes the tension between competing legal orders and ideals in a refugee camp on the Thailand-Burma border. Both the empirical data and most of the literature cited in this case study are directly drawn from her study. ${ }^{5}$ McConnachie conducted a 15-month field research on the Thai-Burma border between 2007 and 2012 including several months living in a camp and working as an English teacher in the camp education system. In addition to numerous informal visits and conversations, she conducted 170 interviews with members of camp administrations, international non-governmental organizations, and others. Although the EU is currently not directly involved in this area, the lessons from this case are highly relevant for understanding the success and failure of the EU's (future) external action aimed at promoting the rule of law. First, the strategy of top-down legal reform followed by the UNHCR and the other donor organizations in this case is similar to the present EU rule of law approach in other countries (see, e.g., Metais et al. 2013). Second, the case clearly illustrates both the limits of a top-down approach and the benefits of a bottom-up approach. Finally, the events on the Thai-Burma border are highly relevant considering the EU's growing interest in Southeast Asia (Schmitz 2012). ${ }^{6}$

\footnotetext{
${ }^{5}$ Many thanks to Kirsten McConnachie (Oxford) for letting me read her book prior to its publication.

${ }^{6}$ See also Manuel Schmitz's paper in this special issue.
} 


\section{Background}

For more than 30 years, refugees from Burma (or Myanmar ${ }^{7}$ ) have been fleeing to Thailand to escape human rights abuses and fighting between armed opposition groups and the Burmese military. At present, more than 130,000 refugees live in refugee camps along the Thai-Burma border (see McConnachie 2014, 5). At first, these camps were relatively informal village-style settlements, but they have been gradually consolidated into large, closed camps (Bowles 1998). Most refugees have fled from the border regions of Karen State and Karenni State. The Karen and Karenni ethnic groups have been fighting for self-determination effectively since the birth of Burmese independence (in 1948) and have experienced intense discrimination and prosecution by the Burma army. Presently there are nine temporary shelters on the Thai-Burma border. Seven of these are "Karen" camps and two of them are "Karenni." More than 20 international agencies and organizations operate in these refugee camps, including the UNHCR and a consortium of donor organizations known as The Border Consortium (TBC). In addition to national and international authorities, much of the day-to-day camp management is handled by refugees, as participants in Camp Committees, and a range of community-based organizations.

This case study zooms in on Mae La Oon. This camp is very close to the Burmese border, in an isolated area surrounded by dense forest and rugged mountains. It has a population of 13,000 and more than $98 \%$ of the population is Karen. They live in simple bamboo huts densely packed together along narrow dusty roads (see McConnachie 2014, 6). Despite the perception that refugee camps are characterized by anarchy and chaos, most camps on the Thai-Burma border "have remained broadly stable and safe, and they have retained strong community structures and social capital" (McConnachie 2014, 8). This is largely due to their own system of dispute resolution. While the Royal Thai Government has legal jurisdiction over the camps, the vast majority of disputes and problems - including theft, domestic violence, gambling, and drug and alcohol abuse - are resolved within the refugee community. Mae La Oon is generally considered to be among the most stable camps on the border, with the fewest serious crimes and most effective justice system (McConnachie 2014, 107). Their local system of "camp justice" is the central focus of this case study.

\section{A top-down perspective}

We will first study the situation in Mae La Oon, using the model of the Rule of Law in Action. We will take the definition of the rule of law as described by the European Commission (2014) as our central point of reference (see "From an anatomical to an empirical approach"). This definition describes what is considered the most desirable relation between the law and the state, focusing on specific ideas about justice, power, and accountability. Our empirical analysis looks at the degree to which these principles are implemented in practice.

\footnotetext{
${ }^{7}$ In 1989, the then-ruling military regime changed the country-name of "Burma" to "Myanmar." Following McConnachie (2014), I have used the name Burma because this continues to be the preference of the refugees and community organizations in this case study.
} 


\section{Due process}

Following the definition by the European Commission $(2014,4)$, the "core meaning of the rule of law" covers several elements of due process, including legality, legal certainty, prohibition of arbitrariness of the executive powers, independent and impartial courts, and effective judicial review. ${ }^{8}$ In Mae La Oon's system of camp justice, however, due process is not considered very important (see McConnachie 2014, 114). Contrary to the ideas of legality and legal certainty, there are hardly any written rules and there is no consistent model of dispute resolution that is applied in all seven Karen refugee camps. According to a report by the Burma Lawyers' Council, "no camp researched has a formally written and agreed to constitution" (BLC 2008, 7). Moreover, "there is no governing Penal Code that is commonly practiced" (BLC 2008, 5). Finally, "[t]o make matters worse, there is no criminal procedural law that is applied within the existing camp courts resulting in the denial of procedural justice" (BLC 2008, 5).

In relation to the prohibition of arbitrariness and access to independent and impartial courts, research shows that in several camps, a single judge resolves cases and disputes, in conjunction with other camp leaders as he chooses. In Mae La Oon, the judges are chosen by the Camp leader and Camp Committee. Here too, judges do not take decisions unilaterally but in consultation with several other members of the community (McConnachie 2014, 107). The Burma Lawyers' Council has serious concerns about the independence of the judiciary from other camp authorities. They also criticize the fact that officials elected to administer justice "are more often than not respected or popular members of their communities, rather than experienced legal practitioners" (BLC 2008, 6). Based on these and other findings, the UNHCR concludes that the camp justice system does "not meet basic standards of due process" and lacks "a clear legal basis, transparency, fair procedures, and trained personnel" (UNHCR, cited in McConnachie 2014, 114). As a result, it is argued that in dealing with cases like theft or domestic violence, the camp-based justice mechanisms "do not systematically work for the protection of victims and the prosecution of perpetrators" (UNHCR 2006, 5).

\section{Human rights}

According to the European Commission (2014, 4), a second important element of the rule of law is respect for fundamental rights and the principle of equality before the law. However, the UNHCR $(2006,36)$ has found that the camp justice system does "not apply sanctions in line with international human rights standards." Moreover, according to the Burma Lawyers Council, "the level of punishment meted out to convicted criminals is not always proportionate to the crime committed" (BLC 2008, 6). This is also considered a violation of international human rights. In its report, the Council mentions a case in which someone who is convicted for rape is only given a relatively small fine. Moreover, it criticizes the fact that criminals who are convicted of serious crimes are often allowed to live within the camp environment days after they have committed their crime. According to several women's organizations, the system of

\footnotetext{
${ }^{8}$ Here, I follow the general definition of 'due process', as used by the UNHCR (2006) and McConnachie (2014). Other writers sometimes make a distinction between 'legality' and 'due process' (see, e.g., Waldron 2008).
} 
camp justice is "male-dominated" and "women, youth and minority groups remain underrepresented" on camp committees (UNHCR 2006, 5). Moreover, the camp justice system tends "not to view sexual and gender-based violence, including domestic violence, as crimes" (UNHCR 2006, 36).

\section{Assessment}

Considering our analysis based on the model of the Rule of Law in Action, this case study offers a rather grim picture of life in Mae La Oon. Two major elements of the rule of law-due process and human rights - do not play a significant role in the community-based system of dispute resolution. The system of camp justice operates without a clear legal basis, there is no procedural fairness, and there are several examples of gender inequality (see McConnachie 2014, 111).

However, from an empirical perspective, it may also be argued that this image of Mae La Oon is colored by one specific (legal and ideological) image of the rule of law. Our case study was aimed at measuring the social impact of the legal values of due process and human rights. The content of these values was based on the definition of the rule of law provided by the European Commission. In our empirical analysis, this definition was more or less taken for granted. But, how do the people in Mae La Oon themselves feel about this definition of the rule of law? What do they consider important? What is their definition of the rule of law? In order to answer these questions, we need to study Mae La Oon from a bottom-up perspective.

\section{A bottom-up perspective}

Rather than applying a closed definition, the model of the Living Rule of Law applies a "working model" of the rule of law (Cotterrell 1992, 38). What do the people in Mae La Oon themselves consider the most desirable relation between the law and the state (or in this case, the camp authorities)? What are their normative ideas about justice, power, and accountability? Here, these principles are considered important ingredients of their ideal of the rule of law. This part of the case study looks at the "subjective dimensions of law" (Holzer 2013, 838). It looks at the rule of law "from below," focusing on "the disjuncture between the goals and assumptions of the legal framework and the reality experienced and desired by the refugees" (Polzer 2007, 22). According to McConnachie $(2014,108)$, camp justice in Mae La Oon is characterized by "a premium placed on the community good rather than individual demands." This is also reflected in two central values, which will be referred to as "harmony" and "social order."

\section{Harmony}

A "quintessentially Karen trait" of camp justice is a strong desire for peace and harmony (McConnachie 2014, 109). Based on this idea, the following phrase summarizes the Karen philosophy of dispute resolution: "If it is a big problem we make it small, and if it is a small problem we make it disappear." This "harmony ideology" is considered more important than elements of procedural justice or due process (McConnachie 2014, 109). In other words, the whole system of dispute resolution in 
this camp is "entirely concerned with the end goal of making a problem 'disappear' and rather less concerned with means of achieving that."(McConnachie 2014, 109).

Building on this ideology, camp judges do not decide cases based on official camp rules, but rather based on a "shared 'common sense' of morality and appropriate behavior" reflecting the (often very diverse) "standards of honesty, truth, duty and responsibility" which are perceived as "authentically 'Karen" (McConnachie 2014, 108/9). In one case, this means telling an adulterous couple that they should respect their marriage vows made before God. But, in other cases, a thief is told that the traditional way set down by the Karen ancestors is to be honest in all things, or a young person who had been fighting is told that he should obey his parents and teachers (see McConnachie 2014, 108).

\section{Social order}

A second important value of camp justice in Mae La Oon is the pursuit of order and the acceptance of authority. The process of dispute resolution and decision-making in the camp is participatory and consensus-based. However, "its primary goal is not the healing or restoration of relationships between individuals [...] but the maintenance of social order" (McConnachie 2014, 109). In Mae La Oon, deviation from the camp rules is generally met with intense disapproval and the importance of obeying rules is universally recognized. Yet, with regard to most sanctions in the camp, the emphasis is on reintegration and rehabilitation as opposed to punishment. In some cases, offenders are sent to a make shift "jail" (often just a simple bamboo hut). The most serious punishment is exclusion or banishment from the camp. Despite the evidently punitive dimensions of these and other sanctions in the camp, these disposals were described as "rehabilitation" and viewed as part of "a process intended to transform offenders into good citizens who can contribute to their community" (McConnachie 2014, 110). For the same reason, an offender's family members are always included in the process of dispute resolution and "the rhetoric is of reform and improvement rather than humiliation” (McConnachie 2014, 111).

\section{Assessment}

The model of the Living Rule of Law does not approach social reality with a specific (legal or ideological) definition of the rule of law but analyzes life in Mae La Oon from a bottom-up perspective. This provides us with a completely different image of this camp. Contrary to the perception that living in a refugee camp gives rise to anarchy and chaos, our case study shows that refugee camps may also be seen as "dynamic societies with their own shared culture and social norms" (McConnachie 2014, 17). Despite the image that refugee camps are spaces where community bonds break down and values disintegrate, Mae La Oon and most other camps on the Thai-Burma border have remained relatively stable and secure with fairly little violent crime (McConnachie 2014, 58). Unlike the grim picture in the previous section, our bottom-up perspective demonstrates how local leaders and community members are motivated by local values of camp justice, which include strong ideas of harmony and social order. To most refugees in Mae La Oon, these values represent two important ingredients of their own ideal of the 
rule of law. This does not constitute some degree of more or less rule of law, but a different understanding of the rule of law altogether.

\section{Lessons for rule of law promotion}

This case study illustrates the strengths and weaknesses of both empirical models of the rule of law, and it demonstrates how these findings may be used to understand the success and failure of rule of law reform. In addition, it shows how empirical research may inform future debates on the EU's external action in general and vis-à-vis emerging powers in particular.

\section{Legal pluralism}

Most rule of law programs in Mae La Oon and elsewhere focus almost exclusively on state-level legal institutions. They consider the camps as "tabula rasa" which need to be inscribed by rules and standards of international human rights and other forms of official law (McConnachie 2014, 159). International aid workers feel that "Thai law is the only law" (McConnachie 2014, 125) and they are less supportive of maintaining a separate system of community supported camp justice. Consequently, international aid programs primarily aim to strengthen the rule of law in refugee camps by promoting access to Thai courts. However, these programs have not been very successful and most refugees still prefer their own system of camp justice. For example, a survey conducted in 2010 among 2.138 refugees in five camps asked those who had experienced crime where they had sought advice. This study showed that two thirds (61\%) of all refugees used several camp structures, and only $5 \%$ went to the UNHCR or NGOs and $4 \%$ went to Thai authorities (McConnachie 2014, 113).

Although current empirical research (based on the model of the Rule of Law in Action) identifies a gap between the rule of law in books and the rule of law in action in these camps, it offers no explanation for this discrepancy. In order to understand why most refugees feel alienated from the official legal system (Holzer 2013), and why most people in Mae La Oon prefer their own camp justice over Thai law, we need to apply the model of the Living Rule of Law. Our case study suggests that the (individualistic) values of the official rule of law are quite different from the (communitarian) values of the refugees themselves. Also, refugees consider involvement with the Thai authorities dangerous as they fear for repercussions against the victim or against the camp. As a result, most Karen refugees on the Thai-Burma border prefer their own local system of camp justice. Or, as one of them puts it, "We don't understand the [Thai] legal system, we don't have the same background. People should have their own law" (McConnachie 2014, 114).

This situation is not unique to the Thai-Burma border. For example, in a study of 13 international refugee situations, da Costa $(2006,21 / 22)$ found that the overwhelming majority of crimes that occurred were resolved by refugees themselves. These data suggest a completely different approach to the role of law in refugee camps. Contrary to the idea that these camps should be regarded as tabula rasa, a camp like Mae La Oon is, in fact, much better understood as a "governance palimpsest," a rich mix of "spiritual beliefs, traditions and customs, moral didacticism and codified law" (McConnachie 2014, 157). Their living law (as well as their own ideal of the rule of law) is 
characterized by a high degree of "legal pluralism" (Merry 1988) and includes their own customs, moral, and spiritual beliefs but also some elements of Thai law.

These findings may assist future rule of law reform. For many years, most international aid organizations regarded state law as "both legal-normatively and ideologically superior to non-state justice systems" (Janse 2013, 189). However, reflecting on the lack of success of these programs, several organizations have now turned their attention to legal pluralism (Tamanaha 2011; Röder 2012; Janse 2013). Based on the findings from the Thai--Burma border and elsewhere, it is likely that future aid programs will be more successful if they shift their focus from state legal institutions to more engagement with communitybased dispute resolution and other non-state justice systems (see, e.g., Harper 2011; Ubink 2011; Van Rooij 2012). The model of the Living Rule of Law can be a useful tool to help further develop this new legal pluralist approach to the promotion of rule of law.

\section{EU external action vis-a-vis emerging powers}

These findings may also inform legal and political debates on the EU's external action vis-à-vis emerging powers like Brazil, Russia, India, China, and South Africa. As noted before, it is often argued that promoting the rule of law "advances both principles and profits" (Carothers 1998, 95). Yet, considering the rapidly growing economic power of these countries, it is likely that future debates will focus more on the "profits" and less on the "principles." For example, a popular argument is that the promotion of the rule of law in these countries will further strengthen their own national economies and this will ultimately benefit the European economy as well. However, there is a growing awareness that most previous "rule-of-law promotion efforts have been disappointing in large part because they don't take enough account of norms and culture" (Brooks 2003, 2322).

This implies that, in addition to potential profits, we also need to focus on the principles. In the past, most international aid organizations thought of promoting the rule of law simply as exporting those values and principles that increase support for human rights and democracy (see, e.g., Pech 2012, 28). However, our case study on the Thai-Burma border illustrates that this "top-down" approach is not always effective. Although this paper is only based on one case study, and more empirical research is needed to support this claim, our findings suggest that a "bottom-up" approach to the rule of law may be more successful. In policy terms, this implies that - in developing its external action vis-à-vis emerging powers - the EU should not only aim at exporting their own "European" values to these countries, but it should also be more open to importing alternative understandings of the rule of law from Brazil, Russia, India, China, South Africa, and elsewhere. Moreover, it is important not only to focus on the way that the governments of these countries understand the rule of law but also on the views of their citizens (Nicolaidis \& Kleinfeld 2012). It is beyond the scope of this paper to specify how this new EU external action policy should be implemented in practice. But, in general terms, it means that before introducing new initiatives aimed at promoting the rule of law, EU policy makers should first conduct a detailed empirical analysis of the local context and existing local norms (Faundez 2001; Brooks 2003). 


\section{Conclusion}

The promotion of the rule of law is one of the central goals of the EU's external action vis-à-vis emerging powers. In this paper, it was argued that, in order to assess the strengths and weaknesses of this policy, we need to supplement the current legal perspective with an empirical approach to the rule of law. Most current empirical research measures a country's compliance with the rule of law, using checklists and other indexes. These studies follow the model of the Rule of Law in Action, which focuses on the gap between the law in the books and the law in action. It was argued that this type of research has several shortcomings. Therefore, an alternative model was introduced. Unlike the current approach, the model of the Living Rule of Law does not focus on the social support but on the social definition of the rule of law. The exploratory case study of a refugee camp on the Thai-Burma border illustrates that both empirical models produce a different picture of the rule law. Seen from a top-down perspective, the case focuses on the fact that due process and human rights do not play an important role in these camps. Unlike this rather grim picture, a bottom-up perspective reveals that local leaders and other refugees follow their own normative ideas of camp justice instead, which include the values of harmony and social order.

As others have demonstrated, the current approach to rule of law promotion still follows a strict rule of law orthodoxy (Golub 2003; Nicolaidis and Kleinfeld 2012, 13; McConnachie 2014, 105). However, empirical research based on the model of the Living Rule of Law makes us rethink three important premises of this conventional approach. First, contrary to the dominant perspective of lawyers and other experts, it enables us to view the rule of law through the eyes of citizens. Second, contrary to the purported universal character of the rule of law, it highlights the contested nature of this idea across cultural borders. Finally, contrary to the state-centered perspective and the emphasis on formal institutions, it also illustrates the importance of the rule of law in non-state situations.

Empirical research thus provides an important alternative perspective on the EU's external action. Moreover, empirical studies based on the model of the Living Rule of Law support what Nicolaidis and Kleinfeld (2012) have termed a "new approach" to EU rule of law reform. Contrary to the current EU approach, this alternative perspective is not solely based on the rule of law in books supported by lawyers, policy-makers, and international aid organizations, but also includes the living rule of law in the everyday lives of citizens.

Open Access This article is distributed under the terms of the Creative Commons Attribution 4.0 International License (http://creativecommons.org/licenses/by/4.0/), which permits unrestricted use, distribution, and reproduction in any medium, provided you give appropriate credit to the original author(s) and the source, provide a link to the Creative Commons license, and indicate if changes were made.

\section{References}

Botero JC, Nelson RL, Pratt C (2011) Indices and indicators of justice, governance, and the rule of law: an overview. Hague J Rule Law 3(2):153-169

Bowles E (1998) From village to camp: refugee camp life in transition on the Thailand-Burma border. Forced Migr Rev 2:11-14

Brooks RE (2003) The new imperialism: violence, norms and the "rule of law". Mich L Rev 101(7):22752340 
Burma Lawyers' Council (BLC) (2008) Analysis on the situation of the refugee camps from the rule of law aspect. Thai J Law Policy 11(1):1-12

Carothers T (1998) The rule of law revival. Foreign Aff 77(2):95-106

Carothers T (2006) The problem of knowledge. In: Carothers T (ed) Promoting the rule of law abroad: in search of knowledge. Carnegie Endowment for International Peace, Washington D.C, pp 15-28

Cotterrell R (1992) The sociology of law: an introduction, 2nd edn. Butterworths, London

da Costa R (2006) The administration of justice in refugee camps: a study of practice (UNHCR Legal and Protection Policy Research Series). UNHCR, Geneva

Dicey AV (1939) Introduction to the study of the law of the constitution, 9th edn. MacMillan, London [originally published 1885]

Ehrlich E (1936) The fundamental principles of the sociology of law. Harvard University Press, Cambridge, Mass

European Commission (2014) Communication from the Commission to the European Parliament and the Council. A New EU Framework to Strengthen the Rule of Law. COM (2014) 158 final. Brussels, 11.3.2014. http://ec.europa.eu/justice/effective-justice/files/com_2014_158_en.pdf Accessed 10 March 2015

Faundez J (2001) Legal reform in developing and transitional countries. In: Van Puymbroeck RV (ed) Comprehensive legal and judicial development. The World Bank, Washington DC, pp 369-397

Fleury-Steiner B, Nielsen LB (2006) A constitutive perspective on rights. In: Fleury-Steiner B, Nielsen LB (eds) The new civil rights research: a constitutive approach. Ashgate, Aldershot, pp 1-14

Fuller L (1969) The morality of law. Yale University Press, New Haven

Golub S (2003) Beyond rule of law orthodoxy: the legal empowerment alternative (Carnegie Endowment working papers, no. 41). Carnegie Endowment for International Peace, Washington D.C. http:// carnegieendowment.org/files/wp41.pdf Accessed 10 March 2015

Hachez N, Wouters J (2013) Promoting the rule of law: a benchmarks approach (Working Paper No. 105). Leuven Centre for Global Governance Studies, Leuven. https://ghum.kuleuven.be/ggs/publications/ working_papers/new_series/wp101-110/wp105-hachez-wouters.pdf Accessed 10 March 2015

Harper E (ed) (2011) Working with customary justice systems: post-conflict and fragile states. International Development Law Organization (IDLO), Rome. http://www.idlo.int/sites/default/files/Customary\% 20Justice \%202\%20-\%20Post-Conflict\%20and\%20Fragile\%20States.pdf Accessed 10 March 2015

Hertogh M (2004a) The living Rechtsstaat: a bottom-up approach to legal ideals and social reality. In: Van der Burg W, Taekema S (eds) The importance of ideals: debating their relevance in law, morality, and politics. Peter Lang Publishers, Brussels, pp 75-95

Hertogh M (2004b) A “European” conception of legal consciousness: rediscovering Eugen Ehrlich. J Law Soc 31(4):457-481

Hertogh M (ed) (2009) Living law: reconsidering Eugen Ehrlich. Hart Publishing, Oxford

Hertogh M (2013) A sociology of the rule of law: why, what, where? And who cares? Recht der Werkelijkheid 34(1):42-46

Holzer E (2013) What happens to law in a refugee camp? Law Soc'y Rev 47(4):837-872

Inayatullah N, Blanley DL (2004) International relations and the problem of difference. Routledge, New York Janse R (2013) A turn to legal pluralism in rule of law promotion? Erasmus Law Rev 6(3/4):181-190

Kahn PW (1999) The cultural study of law: reconstructing legal scholarship. The University of Chicago Press, Chicago

Kochenov D (2004) Behind the Copenhagen facade: the meaning and structure of the Copenhagen political criterion of democracy and the rule of law (European integration on-line Papers (EioP), no. 10). http:// eiop.or.at/eiop/pdf/2004-010.pdf Accessed 10 March 2015

Krygier M (2007) The rule of law: legality, teleology, sociology (University of New South Wales Faculty of Law Research Series, Paper 65). http://papers.ssrn.com/sol3/papers.cfm?abstract_id=1218982 Accessed 10 March 2015

Krygier M (2011) Four puzzles about the rule of law: why, what, where? And who cares? In: Fleming JE (ed) Getting to the rule of law. New York University Press, New York/London, pp 64-104

Manners I (2002) Normative power Europe: a contradiction in terms? JCMS: J Common Market Studies 40(2):235-258

McConnachie K (2014) Governing refugees: justice, order and legal pluralism. Routledge, Abingdon/New York

Merkel W (2012) Measuring the quality of the rule of law: virtues, perils, results. In: Zürn M, Nollkaemper A, Peerenboom R (eds) Rule of law dynamics: in an era of international and transnational governance. Cambridge University Press, Cambridge, pp 21-47

Merry SE (1988) Legal pluralism. Law Soc'y Rev 22(5):869-896 
Merry SE (2011) Measuring the world: indicators, human rights, and global governance. Curr Anthropol 52(3):83-95

Metais R, Thépaut C, Keukeleire (eds) (2013) The European Union's rule of law promotion in its neighborhood: a structural foreign policy analysis (EU Diplomacy Papers 4/2013). College of Europe, Bruges. ttps://www.coleurope.eu/sites/default/files/uploads/page/edp_4_2013_metais_thepaut_keukeleire1.pdf Accessed 10 March 2015

Nelken D (1984) Law in action or living law? Back to the beginning in sociology of law. Leg Stud 4(2):157174

Nicolaidis K, Kleinfeld R (2012) Rethinking Europe's 'rule of law' and enlargement agenda: the fundamental dilemma (SIGMA Papers No. 49). OECD Publishing. doi: 10.1787/5k4c42jmn5zp-en Accessed 10 March 2015

Pech L (2012) Rule of law as a guiding principle of the European Union's external action (CLEER Working Papers 2012/3). T.M.C. Asser Institute, The Hague. http://www.asser.nl/upload/documents/2102012 33322cleer2012-3web.pdf Accessed 10 March 2015

Peerenboom R (2002) Let one hundred flowers bloom, one hundred schools contend: debating rule of law in China. Mich J Int'1 L 23:471-544

Peerenboom R, Zürn M, Nollkaemper A (2012) Conclusion: from rule of law promotion to rule of law dynamics. In: Zürn M, Nollkaemper A, Peerenboom R (eds) Rule of law dynamics: in an era of international and transnational governance. Cambridge University Press, Cambridge, pp 305-323

Polzer T (2007) Adapting to changing legal frameworks: Mozambican refugees in South Africa. Int'l J Refugee L 19(1):22-50

Pound R (1910) Law in books and law in action. Am L Rev 44(12):12-36

Röder TJ (2012) Informal justice systems: challenges and perspectives. In: Botero J et al (eds) Innovations in rule of law: a compilation of concise essays. HiiL/World Justice Project, The Hague, pp 58-61

Schmitz M (2012) The European Union and Indonesia: problems and prospects for a global partnership (EIAS Briefing Paper). European Institute for Asian Studies, Brussels. http://eias.be/sites/default/files/EIAS Briefing Paper April 2012 Manuel Schmitz.pdf Accessed 10 March 2015

Tamanaha B (2004) On the rule of law: history, politics, theory. Cambridge University Press, Cambridge

Tamanaha B (2011) The rule of law and legal pluralism in development. Hague J Rule Law 3(1):1-17

Ubink J (ed) (2011) Customary justice: perspectives on legal empowerment. International Development Law Organization (IDLO), Rome

UNHCR (2006) Analysis of gaps in refugee protection capacity, Thailand. http://www.unhcr.org/457ed0412. pdf Accessed 10 March 2015

van Rooij B (2012) Bringing justice to the poor, bottom-up legal development cooperation. Hague J Rule Law 4(2):286-318

Venice Commission (2011) Report on the rule of law. Council of Europe, Strasbourg. http://www.venice.coe. int/webforms/documents/CDL-AD\%282011\%29003rev-e.aspx Accessed 10 March 2015

Waldron J (2002) Is the rule of law an essentially contested concept (in Florida)? Law Phil 21(2):137-164

Waldron J (2008) The concept and rule of law. Georgia Law Rev 43(1):1-61

Wouters J, Ramopoulos T (2013) Revisiting the Lisbon's treaty's constitutional design of EU external relations (Working Paper No. 119). Leuven Centre for Global Governance Studies, Leuven. http://ghum.kuleuven. be/ggs/publications/working_papers/new_series/wp111-120/wp119-wouters-ramopoulos.pdf Accessed 10 March 2015

Ziegert KA (1979) The sociology behind Eugen Ehrlich's sociology of law. Int J Soc Law 7(3):225-273

Zürn M, Nollkaemper A, Peerenboom R (2012) Introduction: rule of law dynamics in an era of international and transnational governance. In: Zürn M, Nollkaemper A, Peerenboom R (eds) Rule of law dynamics: in an era of international and transnational governance. Cambridge University Press, Cambridge, pp 1-17 